\title{
OEstado da Arte do Procedimento de Mímesis Corpórea do Lume
}

\section{The State of the Art of the Procedure of Lume's Corporeal Mimesis}

Raquel Scotti Hirson ${ }^{1}$ Ana Cristina Colla ${ }^{2}$ Renato Ferracini ${ }^{3}$ 


\section{Resumo}

Esse artigo relata o estado da arte do procedimento de Mímesis Corpórea tal como criado e sistematizado no Lume - Núcleo Interdisciplinar de Pesquisas Teatrais da UNICAMP. Define e conceitua linhas de trabalho desse procedimento em sua pesquisa prática atual: suas articulações com a dança butô e a memória; a mímesis de monumentos; a mímesis da palavra e suas implicações com o conceito de metáforas de trabalho e mapas afetivos descritivos.

Palavras-chave: Procedimento; mímesis; butô; palavra; monumento; metáfora

\section{Abstract}

This article reports on the state of the art of the procedure of Corporeal Mimesis as created and systematized at Lume - Interdisciplinary Nucleus of Theater Research of UNICAMP. Defines and conceptualizes lines of work of this procedure in her current practical research: the articulations with the butoh dance and the memory; the mimesis of monuments; the mimesis of the words and its implications with the concept of metaphors of work and descriptive affective maps.

Keywords: Procedure; mimesis; butoh; word; monumento; metaphor

\footnotetext{
${ }^{1}$ Doutora e mestre pelo Instituto de Artes da UNICAMP. Atriz-pesquisadora do Lume. Profa. Colaboradora e orientadora do Programa de Pós-Graduação em Artes Da Cena do IA, UNICAMP desde 2015 - raquel@lumeteatro.com.br

2 Doutora em Artes pela Unicamp. Atriz-pesquisadora do Lume. Professora e orientadora no Programa de Pós-Graduação em Artes da Cena - Unicamp - anacristina@lumeteatro.com.br

${ }^{3}$ Prof. Dr. Instituto de Artes no Programa de Pós-Graduação em Artes da Cena - UNICAMP. Ator-pesquisador do Lume. - renato@lumeteatro.com.br
} 
A mímesis corpórea tem como um dos seus pressupostos primeiros lançar o ator em uma zona de experiência intensiva no contato direto com o outro, seja esse outro uma pessoa, um objeto, um animal, uma imagem, um prédio, uma palavra. $\mathrm{E}$ ambiciona que esse encontro potencialize a transformação e recriação do corpo singular daquele que atua-observa.

Um dos mecanismos práticos adotados, que potencializa o encontro, é colocar o ator em situação de viagem. Aqui viagem no sentido literal, fazer sua malinha e ir para o mundo, de preferência levando um repelente. Deixar o seu lugar de conforto, sua cama quente, sua comida preferida, seus entes queridos, suas acomodações e ir ao encontro do desconhecido, do não explorado, de novos mundos. Normalmente partimos em viagem com um roteiro apenas esboçado, deixando que o caminhar redefina o próprio caminhar a partir das afetações do campo: encontros alegres, partida prorrogada, encontros tristes, "quando sai o próximo ônibus? (ou barco, avião, carona, balsa, metrô)". Nos lançamos, de peito aberto, a uma zona de experimentações, bem turbulenta na maioria das vezes. Atentando que, nesse caso, encontros alegres que potencializam, nem sempre são aqueles que nos acariciam, muitas vezes são aqueles que doem ou causam repulsa, mas chacoalham e desacomodam, provocando a potência da ação numa direção não esperada.

Porém, nos últimos anos, também geramos outros procedimentos não necessariamente baseados na viagem literal, mas em uma pesquisa de campo, uma observação que busca deslocamentos de memória, desvios imagéticos, luxações de gestos normatizados que buscam gerar impulsos que promovam o corpo à possível geração de ações potentes. Uma viagem não espacial, mas um deslocamento estando no mesmo lugar. Todo um devir-viagem.

E é desse território de experiências múltiplas - viagens literais e devires-viagens - que baseamos a busca da mímesis. Não a busca de um comum, de uma identidade nacional, de uma catalogação de gestos e trejeitos, seja dos idosos, dos povos ribeirinhos ou dos moradores de rua, da memória pessoal, dos prédios, dos monumentos, das fotografias. Vamos em busca de singularidades, de multiplicidades, da diferença. $E$ de sermos afetados para possivelmente afetarmos. Estamos em busca de um encontro que realiza deslocamentos qualitativos. Acima de tudo um encontro que produza afetos e "buracos", que produza sensações e "saltos", que produza impulsos e lugares "vazios". Pois são justamente nesses buracos, saltos e lugares vazios que nós do Lume trabalhamos, exploramos, reinventamos nosso corpo. Pois, "Trata-se, aqui, de um devir animal que se desencadeia a partir da apreciação da mosca, mas não é a identificação com as formas da mosca que se revela essencial" (Gil, 2012, p.4). Nos espaços, saltos e fendas entre esses sinais é que a mímesis produz sua inventividade corpórea.

Se entendemos o corpo como âncora de experiência, como memória, o corpo singular como potência-outro-corpo intensificado nele mesmo e partindo dessa desterritorialização que a pesquisa de campo em toda sua multiplicidade provoca, ao voltar para sala de trabalho, impregnado de toda vivência desses encontros múltiplos (de novo reforçando: sejam esses encontros com pessoas, cheiros, paisagens, sabores, ausências, sensações, memórias), esse mesmo corpo se reterritorializa, dando passagem a matrizes ou formas de força (formalizações singulares de cada ator), virtualidades e intensidades atualizadas em continuum no tempo-espaço cênico mais potentes, ou ao 
menos, em multiplicidade, com novas aberturas e possibilidades de combinações.

O ator, na mímesis, faz um recorte no fluxo do acontecimento e na velocidade da experiência vivida e busca agenciamentos singulares para dizer-se a partir desse novo lugar. Se revira em busca de elementos que materializem as afetações ocorridas nesse território da experiência, ações, palavras, estados, olhares, a dança que transborda desse corpo em vida no qual as afetações, linhas de força, continuam a circular, se atualizando continuamente. A mímesis, em última instância, tem o objetivo maior de sempre devir-outro a partir de vários procedimentos.

Tadashi Endo nos fala em sala de trabalho 4 que Zeami escreveu algo parecido com Ken Kotsi Da Tai. Ken Kotsi significa: trocando os ossos. Da Tai significa: escapando do corpo. Conta ele para os atores: "Você encontra um gato e neste momento troca os seus ossos por aqueles do gato. Então você escapa do seu corpo e o coloca naquele de um gato. E o gato vê você: Ah, sim, chegou meu amigo, então podemos brincar juntos. Neste momento acontece Ken Kotsi Da Tai; alguma coisa acontece, é uma metamorfose real. Não é uma maneira intelectual de mudar seu estilo ou posição do corpo. Você realmente é um tipo de louco. E o seu corpo muda nesse momento e acontece algo que nós não podemos entender, e causa uma fascinação".

José Gil (2005, p. 294) nos descreve, em outras palavras, algo muito parecido:

O devir-outro parte de uma situação já instável, de disposição para o devir. O corpo deve ser definido como um complexo de possíveis, a cada momento dado: vira-se para outra coisa que não é ele próprio. Mas os possíveis não são unicamente função da anatomia e da fisiologia do corpo que os limitariam a potencialidades motoras; são sobretudo função da imaginação corporal (que cria as condições de exercício da percepção e da ação): os possíveis são aqui os possíveis atualizados pelo ponto material nos seus devires.

Ou ainda:

Para que haja devir-outro, para que alguém consiga "entrar" na pele do outro, tem que se realizar uma metamorfose completa de si próprio; não basta imaginarmos simplesmente peixe (desencadeando o trabalho de uma "faculdade" ou de uma "função") para nos tornarmos-peixe; ao mesmo tempo, teremos que deixar de ser homem, de viver o corpo como corpo humano, e nos deixarmos atravessar pelas energias e intensidades do peixe. (Gil, 2005, p. 293-294)

De certa forma, podemos afirmar que a memória é o elemento comum em todas as vertentes da mímesis. Seja a memória do encontro, da imagem do outro fora, do espaço à volta, seja a atualização de fragmentos de memória, vivido ou imaginado. Memória enquanto duração, de um presente que se acumula num passado, e que se torna novamente presente carregado de todo o passado anterior, numa atualização do vivido no presente. A memória como detonadora de poéticas.

Então surge a pergunta: o que difere a formalização de forças dos vários estímulos recentemente pesquisados nesse devir-outro da mímesis de forma individual por cada ator em cada processo de trabalho? E para nos aproximarmos dessa pergunta,

${ }^{4}$ Conversa em sala de trabalho na Sede do LUME entre Tadashi Endo e os atores no processo de criação do espetáculo Você em 2009. Relato publicado em Colla, 2013, p.132. 
não para encontrarmos uma resposta fechada, devemos pensar cada uma delas enquanto um território particular, um espaço de forças múltiplo. Portanto, para melhor delimitar esse território temos que mapear os atravessamentos que compõem essas formalizações, quais são os seus contornos - ao menos os que forem possíveis e visíveis aos nossos olhos ou consciência (sabendo que mesmo assim ficarão de fora todas as forças que a nossa consciência não conseguir nomear ou nossos olhos do visível não puderem ver).

Para que essa visualização inicial dos procedimentos vários fosse possível nos atemos ao que chamamos de "mapas de afetações". Nesses mapas cartografamos sobre qual fundo essa forma de força se originou. Qual paisagem deu origem a ela? Procedimentos de criação, diferenças na condução, interlocutores, processos distintos que a originaram e que interferem em sua poetização. Dessa forma, nos anos anteriores, cada ator, em sua verticalização de trabalho, enumerou alguns procedimentos diferenciados que ampliaram a ação da mímesis para a construção desse devir-outro. Descrevemos abaixo alguns desses procedimentos com exemplos de mapas afetivos para cada um deles:

\section{A Mímesis, o Butô e a Memória}

Nas interlocuções e contaminações com o butô, mais especificamente com os bailarinos Natsu Nakajima ${ }^{5}$, Anzu Furukawa ${ }^{6}$ e Tadashi Endo ${ }^{7}$, novas experimentações e limites foram vivenciados e surgiram novos padrões e agenciamentos na investigação de uma dança singular.

Logo em 1995, após o falecimento de Luís Otávio Burnier (idealizador e fundador do Lume), em pleno luto, Natsu Nakajima nos presenteia com um mês de trabalho. Nos colocou para dançar a ausência do nosso mestre e pessoa querida a ela também e juntos fomos nos reerguendo, nos entrelaçando, nos fortalecendo. Nos

\footnotetext{
${ }^{5}$ Natsu Nakajima (1943 -) dedicou toda a vida à dança Butô sendo um dos membros fundadores desse movimento e uma das principais pioneiras dessa dança fora do Japão. Aos 19 anos, ela entrou no Kazuo Ohno Dance Studio e apenas um ano depois começou a trabalhar com Tatsumi Hijikata. Treinando com esses dois grandes mestres, Nakajima, em 1969, estabelece sua própria companhia de dança chamada Muteki-sha, onde atuou e coreografou internacionalmente desde o início dos anos 1980. Além de seu desempenho e trabalho coreográfico, foi uma das precursoras da dança para deficientes no Japão. Nakajima intercambiou seus trabalhos com os atores do Lume em encontros intensivos nos anos de 1994, 1995 e 1996. (Fonte: arquivo do Lume)

${ }^{6}$ Aos dez anos Anzu Furukawa (1952-2001) começou sua carreira de dança. Entre 1962 e 1970, estudou ballet clássico no Umeko Inoue na Escola de Ballet em Tóquio e dança moderna 1969-1970 em Zenkō Hino. De 1972 a 1975 estudou composição e piano no Irino Yoshiro. Participou ativamente do segundo movimento de desenvolvimento do Butô japonês, ocorrido em meio às perturbações sociais da década de 1970 no Japão, em uma atmosfera marcada por protestos estudantis, luta de rua e atos de agitprop . Em 1974, Furukawa juntou-se ao lendário Butoh Compagnie Dairakudakan sob a batuta de Akaji Maro e lá permaneceu até 1979. Juntamente com Tetsuro Tamura fundou o grupo Dança Love Machine Ensemble (1979-1986). Em seu trabalho de dança havia colaborações com Carlotta Ikeda, Murobishi Ko e Ushio Amagatsus Sankai Juku. Anzu Furukawa esteve no Lume em 1997 e dirigiu o espetáculo AFASTEM VACAS QUE A VIDA É CURTA com seus atores e atores convidados. (Fonte: arquivo do Lume)

7 Tadashi Endo nasceu em 1947, em Pequim, na China, mas é de família japonesa. Em 1973 a 1976 iniciou seus estudos em direção teatral, assim tendo mais contatos com as técnicas ocidentais com o Instituto Max Reinhardt Seminar, em Viena. A partir de 1982, começou a fazer performances de dança com grandes músicos do jazz, como: T. Kondo, A. Takase, M. Sato, K. Umezu, St. Lacy, C. Bauer, P. Kowald, G. Sommer, U. Gumpert, G. Gebbia, Gunter Hampel. Em 1989 conheceu Kazuo Ohno e, a partir de então, começaram uma parceria que se estendeu por muitos anos. Em 1992, fundou o Butoh-Center MAMU na cidade de Göttingen, uma cidade universitária alemã. O Trabalho de Tadashi se baseia no conceito de butoh-MA. O nome do instituto é a combinação de duas palavras do zen budismo, o MA e o MU, que juntas lembram as primeiras palavras proferidas por crianças. MU significa empitness (vazio), MA significa espaço entre as coisas, é o tempo entre o final de um movimento e início de outro. O Butoh-Center MAMU promove diversos cursos para os estudantes universitários de Göttingen, além do MAMU Festival. Tadashi Endo vem mantendo intercâmbios de trabalho contínuos com os atores do Lume desde 2004 quando dirigiu o espetáculo SHI-ZEN, 7 CUIAS. Depois dirigiu o espetáculo SOPRO (2005), solo do ator Carlos Simioni e VOCÊ (2009), solo da atriz Ana Cristina Colla.
} 
presenteou com imagens e pequenas coreografias de poemas de Hijikata, com quem havia trabalhado. Um mundo de sutilezas e cores se abriu. Vê-la dançar em nossa sala de trabalho é uma imagem que nos percorre e emociona a cada vez que a acessamos. Ver seu corpo miúdo, aparentemente frágil, se agigantar e nos fazer flutuar, sem que a nossos olhos nada de concreto estivesse sendo feito, fez-nos sentir essa atmosfera quase mágica do corpo enquanto potência, esse enovelar no espaço, dobrando-se e desdobrando-se. Nas palavras de Ana Cristina Colla $(2014$, p. 87) sobre esse período:

Com ela me apaixonei por esse lugar/estado em que os princípios dessa dança, ali sutilmente vividos, me lançavam. As imagens, já presentes em meu trabalho, redobraram enquanto força e sentido. Com ela também conectei as imagens (pictóricas ou da imaginação) com as imagens poéticas de textos e palavras e passei a dançá-las. Acabei por criar a partitura/série de ações da cena de abertura e a da Maroquinha, no espetáculo Café com Queijo, a partir desse olhar. Me assustou o "fantasma", esse corpo livre, sem passado nem futuro, ausente de desejo, que pode ser pedra, névoa, flor, barro, que escova os dentes e vira passarinho no ninho. Se antes, com as viagens provocadas pela mímesis, meu olhar se expandiu para as pessoas que me cercam, suas cores e riquezas imensas, tocar no fino véu do butô que pude antever nessa breve experiência, abriu meu corpo para dançar no tempo, implodindo o espaço, me fazendo sensação e comunhão.

Em 1996 tivemos um novo encontro com Natsu Nakajima, e em 1997 recebemos por três meses a visita de Anzu Furukawa, de cujo intercâmbio nasceu o espetáculo Afastem-se Vacas que a Vida é Curta (1997). Já nessa época desejávamos trabalhar com a obra Cem anos de solidão, do escritor Gabriel Garcia Marques, e partimos para uma nova viagem de pesquisa de campo, agora para o Amazonas e o Pará, em busca da corporeidade dos povos ribeirinhos. Anzu aterrissa no Lume meses após o nosso retorno da Amazônia. Neste interim havíamos trabalhado sozinhos em sala de ensaio manipulando o material coletado. Quando o furacão Anzu chega - quem a conhece sabe que ela era um furacão intenso e vibrante - implodindo, sacudindo, todas as nossas certezas foram sendo redefinidas, ganhando novas arestas. Anzu nos fez dançar. Com coreografia e tudo. Pôs a mão na massa, literalmente, de nossos corpos e com golpes firmes e mãos potentes foi nos fragmentando, lapidando, exaustivamente. Entre choros, marcas roxas espalhadas pelo corpo, dores musculares e certo carinho velado, fomos intensificando a cada dia o nosso encontro. Sobre uma das cenas desse espetáculo podemos ler enquanto mapa afetivo:

Nesse espetáculo construímos a cena "Porra", representando as personagens Úrsula e Amaranta do romance de Marques, entre mim (Ana Cristina Colla) e a atriz Ana Elvira Wuo, partindo de uma dilatação e desconstrução da corporeidade observada. Ela nos pedia corpos com 180 anos. O que nos levou a ampliar e extrapolar cada uma das tensões musculares presentes, numa composição entre várias mímesis observadas, instalando uma nova dimensão que implodia o uso habitual do corpo (sensação essa que fui provar novamente anos depois, por outras entradas com a construção da Velha, no solo "Você" com direção de Tadashi Endo). Potencializando o que a cena ambicionava enquanto revelar a incomunicabilidade e a solidão entre os seres humanos, tendo como exemplo a mãe e a filha. Tudo isso com o corpo seminu, sob um carrinho móvel, cheio de penduricalhos e buzinas, onde o único texto falado era: "Onde está?", "O quê?", "O animal", "Aqui". (Colla, 2014, p. 88) 
Anzu nos apresenta os extremos, a extrapolação dos limites, o corpo em sua intensidade máxima. E o encontro da mímesis com a dança.

Já com Tadashi Endo vivenciamos a busca da desautomatização do corpo e dos sentidos, desestabilizando referências, obrigando o corpo a encontrar novas vias de saída. Com ele aprofundamos o trabalho intenso com as oposições e paradoxos do corpo (dentro-fora, ativo-passivo, expansão-contração, tensão-relaxamento, forte-fraco), descondicionamento da percepção provando extremos de velocidades ou a suspensão dela (lento-rápido, muito lento-muito rápido, ficar imóvel ou sentar e levantar por 30 minutos, se equilibrar em um pé só por 40 minutos). Provamos um corpo espástico, comprimido, impotente, dançando o desconforto, o contraste, a resistência, a desarticulação e a dissociação das partes.

Assim como o butô não propõe uma formalização corpórea fechada, mas experimentações para a elaboração de uma elaboração técnica pessoal - algo palpável e perceptível quando vemos diferentes dançarinos de butô e suas danças singulares cremos que a mímesis também provoca em cada um de nós, atores do Lume, olhares distintos e apropriações diversas. Sempre em atualização, construção e desconstrução, de acordo com os atravessamentos que cruzam nossos caminhos particulares.

E cada uma dessas vivências, desses tensionamentos, provocados pelos encontros, nos lançam para territórios distintos de experimentação. E como não são territórios fechados em si, mas relacionais e em constante atualização, só podem se compor com outras forças.

Outra questão que aproxima o butô da mímesis é o trabalho com a corporificação da memória. Já que o corpo é memória, como fazer com que ele encontre seu limite, que recrie suas memórias em ação ou mesmo que gere memórias presentes que enraízam a ação física em uma experiência concreta? Este é um terreno comum tanto para o butô como para os procedimentos de mímesis tal como construídos no Lume. "Dançar o ácaro" na pele, assim como "fazer com que milhares de borboletas saiam voando de suas têmporas" (um exercício proposto por Tadashi Endo) tem o mesmo objetivo de, por meio dessas metáforas de trabalho, lançar o corpo em estado de limite para possivelmente fazer nascer uma ação física potente.

As metáforas de trabalho podem gerar realidades em linha de fuga e talvez criem fissuras dentro de uma realidade engessada. Podem levar o corpo a experimentar novas possibilidades de ações, de vibrações, de criação artística. É uma ida às bordas, às vizinhanças, às linhas de potência liminar nas quais as definições inteligíveis e lógicas não alcançam mais.

O que se experimenta no trabalho prático do atuador não é somente a metáfora como figura de linguagem, mas principalmente como detonadora de ação. É com um conjunto de práticas composto e instigado pelas metáforas de trabalho que o corpo se alça para fora de seu sentido/comportamento de doxa cotidiana. Portanto, é perfeitamente possível um condutor de trabalho pedir que o bailarino "dance como uma rosa que desabrocha". E é justamente o ingresso dessa nova metáfora no conjunto de um sistema de práticas corpóreas cotidianas enrijecidas que pode conduzir nossas ações para um novo território e alterar as percepções, micropercepções e as ações a partir da imagem dada. Por isso cada grupo estabelece seu processo de trabalho a partir de metáforas muito particulares que são detonadoras de desterritorializações 
e reterritorializações no conjunto de práticas daquele artista ou grupo específico. 0 butô possui suas metáforas e o Lume as suas.

A metáfora de trabalho, portanto, pode proporcionar, a partir dela mesma, esse trânsito não dualista fora-dentro e pode re-compor, nesse encontro, o corpo em uma fronteira criativa.

Abaixo um exemplo das metáforas utilizadas pelo Tadashi em sua condução imagética do trabalho:

Suas pernas são as árvores. O quadril é o cachorro. Uma história diferente para cada uma das mãos, das pernas, do quadril. Todas as partes são independentes. Sua mão não é sua mão. Seu pé não é seu pé. Seu ombro é da sua mãe. Seus dedos são peixes. Mais memória dentro, muito pequeno fora. (Endo in Colla, 2013, p. 67)

Como se pode perceber, a metáfora se afasta do raciocínio lógico-objetivo e pode lançar o corpo em um pensar-em-ação. A metáfora de trabalho estabelece uma nova lógica não-intelectual: a lógica da prática corpórea; a lógica de uma potência de sensação-peixe-árvore-cachorro. A aceitação e a resultante prática dessa metáfora provocou e resultou em ação.

Podemos pensar de forma rápida que o que ocorre nesse exemplo é uma possível "tradução" de um comando verbal para a ação física. Mas essa tradução não pode ser pensada, de forma alguma, como a representação de um signo verbal e imagético por um signo corpóreo. Isso seria reduzir a potência da metáfora de trabalho a questões meramente representativas. O corpo não simplesmente representa a metáfora de trabalho, mas essa gera uma potência de criação corpórea, de um pensamento- prática que pode lançar o corpo em um estado de liminaridade e experimentação. A metáfora de trabalho gera potência corpórea e não tradução representativa e potencializa muitos corpos possíveis na construção lugar-comum de nossos corpos.

Tadashi Endo, em seu trabalho com o Lume, aprofunda as várias camadas e corpos simultâneos que transbordam das palavras criando imagens que serão dançadas. "Um corpo tem muitos corpos dentro de si", nos diz Tadashi. E ele recria e "exprime" - aqui no sentido etimológico "errado" de espremer - esses outros corpos a partir de imagens que sugerem cor, ritmo, vida, sonoridades e que se transbordam em novas imagens, originando outras e assim infinitamente. Esfumaçando/desdobrando/multiplicando a palavra/imagem inicial até seu borramento total, tornando mais e mais abstrato, mas ainda assim mantendo os elementos e acentos da imagem inicial. Dessa forma ele condensa as imagens resultando num minimalismo das ações.

É dessa forma que no butô e na mímesis tudo é possível e nada é impossível. A questão que atravessa ambos os procedimentos: como dançar essa abstração partindo de um corpo concreto? Podemos dançar o abstrato, mas não podemos ser abstratos. Dançar a zona "entre", que reside entre a abstração do movimento/imagem e o concreto do corpo.

Um exemplo de mapa afetivo na geração de uma ação física que enlaça butô, mímesis e memória da atriz Ana Cristina Colla na construção de seu solo -Você, com direção de Tadashi Endo: 
Para a construção da dança da velha, não utilizei a observação de ações do cotidiano como nas experiências anteriores com a mímesis corpórea. A dança da Velha, que compõe o espetáculo solo - Você, foi sendo construída, antes mesmo que soubéssemos que ela estaria na cena, como qualidade de vibração e espaços corpóreos. Seguramente toda a vivência anterior com a mimese de idosos era uma camada permanente, presente em todas as ações executadas. Elementos como ritmo, respiração, musculatura condensada, a vulnerabilidade do corpo idoso, entre outros, eu já havia experienciado seja em sala de trabalho, seja em sua transposição para a cena. A velha foi se vestindo de camadas, finas películas, árvore, vazio, vibração, atmosfera, memória, imagens. No início da construção da corporeidade da velha, minha única preocupação era na manutenção da forma física. Pernas separadas, peso na parte de fora dos pés, joelhos flexionados voltados para fora, púbis projetada para frente, peito pesando para baixo, braços levantados na altura dos ombros, cotovelo para fora, pulso quebrado para baixo, espaço entre os dedos, tensão nas mãos, pescoço e cabeça projetados para frente, lábios escondendo os dentes, sobrancelha levantada, olhos espremidos. O desenho corpóreo foi se tornando cada vez mais nítido e todo meu esforço era no comprometimento muscular que essa postura me exigia. Como deslocar o peso, realizar pequenas ações, olhar, respirar. Ficávamos improvisando longamente dentro dessa qualidade, o que me exigia muita concentração. Eu não pensava em fazer um corpo velho, ou reproduzir uma velha observada. Eu nada pensava. As dificuldades eram reais, físicas, efetivas, sensoriais e não precisavam ser imaginadas. Essa concentração absoluta, num esforço real, mostrou ser a chave, o ponto central de entrada para essa dança. A partir daí, pude ir vestindo outras camadas e construindo a atmosfera à volta. Toda a ação se passa num tempo dilatado, com pouquíssimos elementos externos como suporte para a instalação da atmosfera. Meu maior desafio é instalar o espaço tempo poético da cena, tendo como único apoio o corpo e o espaço projetado por ele. [...] A dança da velha encontra seu espaço poético no nível da micropercepção. Dançar a contradição entre um corpo ressecado, velho em seu exterior, mas que mantém sua juventude pulsando internamente através das memórias que cultiva. O corpo velho que tem a memória do corpo novo. Precisei antes habitar a velha que um dia serei. Uma viagem ao futuro para encontrar o passado. No Corpo da Velha, eu mesma, dançando a paisagem de todos os corpos que um dia habitei e que me habitaram. E os que ainda virão e que hoje se manifestam como virtualidade, como potência. (Colla, 2013, p. 140,141)

Se pensamos em uma dança em devir: "devir não é imitar, nem simular, é se lançar entre você e o que você será. É um devir-desconhecido, imperceptível” (Uno, 2012, p.44), poderia dizer que esse é um dos centros que movem a pesquisa da mímesis corpórea, um devir outro continuando a ser o que se é, um corpo aberto, sem forma definida, meio homem, meio animal, meio planta. Não a busca por uma identidade fixa ou catalogação de trejeitos ou matriz original, mas experimentação de diversos fluxos, de uma dança que vai se construindo de vivências. (Colla, 2014, p. 75)

\section{A Mímesis da Palavra e, novamente, a memória}

A primeira vez em que a mímesis foi assim denominada, embora na prática já tivesse sido experimentada em outros contextos e pesquisas do Lume $^{8}$, foi durante o processo de doutorado de Raquel Scotti Hirson, Alphonsus de Guimaraens - Reconstruções da Memória e Recriações no Corpo, 2012. O objetivo da mímesis da palavra é fazer com que a palavra se proponha uma construção poética no corpo. A palavra não somente compreendida como unidade da linguagem escrita, mas como 
uma abordagem textual, seja ela poética ou não. Neste caso específico, sua primeira denominação como ramificação da mímesis corpórea, surgiu conectada à poesia e às memórias de infância, em uma conexão ficcional entre a criança que recria a memória de seu bisavô poeta, o qual nunca conheceu.

Poesia corporificada em forma de ações físicas. Para que a poesia seja recriada, a imagem da infância deve ser igualmente recriada e revivida em abundantes sensações que vêm e vão, em vetores de direções diversas, em saltos no tempo e na memória. "Um excesso de infância é um germe de poema" (Bachelard, 1988, p. 95). Neste caso, o artista deve ser tomado de infância, mais precisamente de um devir-infância, e se perder nas dimensões da lua, como nos instiga o poema de Alphonsus de Guimaraens para ser lançado a ela com toda a paixão de Ismália (Guimaraens, 1960, p. 231), imagem vivida e transformada, transposta para a linguagem do corpo. Virtualidades que se presentificam na recriação da infância, nas imagens da infância, nas palavras do poeta que se nos tornam ausentes a cada vez que fechamos o livro, mas que se atualizam em nossas memórias e imaginação, ou a cada nova leitura. A palavra passa a ser corpo-em-ação em nosso trabalho. O corpo-em-ação como recriação de virtualidades. A poesia se torna palavra, no corpo.

Mas temos também as imagens da memória. Em devaneio poético do corpo, adentramos em estados de percepção aguçados e entramos em um fluxo que conflui pensamento, ação, músculo, memória, fantasia, imagens enfim. O pré-impulso, o desejo (antes mesmo do impulso muscular), desencadeia esta totalidade e emerge feroz no campo do devaneio, que não produz mais somente recordações, mas sonho. A memória salta descontinuamente e produz imagens, em constante recriação e valoração. A recriação é reencontro com o passado, mas de um passado incompleto na memória datada, que pode, portanto, ser recriado em novos voos através de imagens, que completam as lacunas da memória. A dança da musculatura e da respiração pressiona a atualização de imagens que dançam na mente-corpo e produzem memória de imagem e sensação, até mesmo sem nome conhecido ou data. São fantasmas que invadem o corpo físico e o conduzem no espaço.

Não se trata em absoluto de representar a poesia e sim de recriá-la, em um fazer teatral não-representativo. Desta forma adentramos em uma questão diferencial da mímesis corpórea: a mímesis da palavra. A palavra em ação pode conter todas as dimensões das conexões de imagens que detona e ainda as dimensões do corpo, jogando com espaço e tempo. A palavra poetizada sugere sons, tensões, ações que tomam outras formas e sugerem novas poesias quando corporificadas. Um emaranhado de recriações que afeta e gera re-atualizações de dimensões poéticas, afeta o observador, que por sua vez recria sua poesia.

A construção do corpo cênico, na mímesis, passa pela observação ativa e não é diferente na mímesis da palavra. O que difere, nesta pesquisa, é a dimensão que a observação adquire, considerando-se o advento da memória. Trata-se de uma forma rizomática de criação, e a sensação é mesmo de rizomas chegando por baixo e

\footnotetext{
${ }^{8}$ Por exemplo, em 1999, quando da criação do espetáculo “Um Dia...., no qual buscou-se dançar contos e poemas que remetessem ao corpo em trauma (Direção de Naomi Silman e atuação de Raquel Scotti Hirson e Ana Cristina Colla). Em 2009, o espetáculo Você foi construído a partir da criação e da dança de poemas da própria atriz, Ana Cristina Colla.
} 
por trás. Os poemas, as imagens ou os documentos estão e estarão sempre sendo atravessados por uma história que irrompe o espaço-tempo criativo e desestabiliza a narrativa do corpo.

Burnier suspeitava que a mímesis corpórea precisava da dança pessoal e hoje percebemos que, não somente a dança pessoal, mas a memória dá suporte à mímesis corpórea assim como, vice-versa, a mímesis corpórea se apresenta como uma alternativa para a memória, como uma reconstrutora, criadora de uma memória totalmente esgarçada, formada de fotografias, impressões de infância, odores e as fortes impressões que são mistério, e que vão tomando corpo.

O mesmo se dá com a palavra. Quando selecionamos um verso ou um poema, em um lapso de segundos, essa imagem se atualiza em pensamento e é fisgada, desacelerada e, em fração de segundos se torna corpo - imagem plena corporificada e em ação. Neste caso, a mímesis da palavra toma uma dimensão enorme, pois cada lapso de pensamento pode vir a ser uma imagem fotografada na memória ou pode se atualizar em movimento ou pode, ainda, ser hiper-penetrada, como um microscópio sensível às imagens, que adentra no campo das micropercepções. Então, uma imagem que surge no pensamento, não gera uma dicotomia, mas, ao contrário, ativa o corpo em lugares recônditos que podem ser acionados pela presença da imagem no pensamento. Por outro lado, a mesma gama de possibilidades se dá no corpo, que re-poetiza a poesia, que pensa a poesia em ação, que adentra em campos de intensidade a cada nova imagem dançada, recriando poesia, re-poetizando, recriando poesia no corpo, corpoetizando.

Em outras palavras, na mímesis corpórea, o pensamento-corpo se constrói a partir da observação de estímulos diversos. Essa tensão (zona de confluência) que acontece entre uma coisa e outra é algo que atravessa, necessariamente, o observador, gerando um estado de abertura que se completa em impulso-ação mimética, ou seja, ação no espaço.

A partir do momento em que o foco de observação toma corpo e se recria em ação física, a explosão passa a ser semelhante à de qualquer outra ação em intensidade, pois se trata de memória tanto quanto no caso da dança pessoal ou do treinamento energético. A memória pensa em fluxo de ação, tudo concomitantemente. $O$ pensamento é ação. Em qualquer dos casos haverá aspectos incorpóreos intensivos e partículas virtuais a serem percebidas e recriadas. Haverá sempre um paradoxo entre precisão e imprecisão, pois as virtualidades podem ser imprecisas. Desta maneira, haverá sempre espaço para recriações, pesquisa e encontros. Mais uma vez espaços vazios, saltos, fissuras, ocos; uma imprecisão necessária.

O que pode nos dar suporte é a realização de um mapa afetivo imagético e de memória que impulsione o corpo à ação. Um exemplo é o mapa afetivo da atriz Raquel Scotti Hirson sobre o procedimento da mímesis da palavra no processo de seu solo: Alphonsus. Ela configura a mímesis enquanto produtora de ação física com âncoras-sinais que provocam no espectador a imagem de uma figura, humana ou não, mas que permitem muitos espaços vazios entre essas âncoras-sinais que precisam ser preenchidos. 
Alguns deles impossíveis de serem codificados, pois deve sempre restar espaço para que ocorra o encontro efêmero entre ator e espectador. Se não percebemos a presença desses espaços e se não os preenchemos com respiração, imagens, sensações e relação, fica uma montagem de ações que pula de uma coisa para outra. Estes saltos talvez sejam os responsáveis pela observação que faço a respeito de nosso trabalho. Por isso, preenchi esses espaços com tantas imagens e memórias, ou, por exemplo, preenchi de imagens de Barthes (2009). Com Barthes, assim como com Alphonsus, encontrei na mímesis da palavra um canal de preenchimento de espaços vazios deixados pela observação de fotografias e pessoas. Avolumei-os. Em Barthes encontrei possibilidades de emparelhamento, pois as sensações de seu diário de luto perpassam imediatamente o corpo, visto que muitas delas foram vividas por nós também. Podemos não ter vivido a perda exatamente como a que ele descreve, mas vivemos perdas e encontramos lugares semelhantes no corpo para localizá-las. No caso das fotografias das festas familiares, por exemplo, me interessava possibilitar ao espectador a sensação de estar folheando um álbum de fotografias, mas, ainda assim, as ações pedem preenchimentos. Optei por trabalhar com as imagens exageradas, ampliadas do original e os espaços entre elas foram preenchidos com ligações [ligamens segundo Burnier - (2001)] em que sempre sobra um pouco de uma fotografia naquela que se segue. Além disso, me coloquei o desafio de dançar a sequência sobre e ao redor da mesa, em um espaço que mal cabiam meus pés, e de alimentar as transições com um pouco de dança de baile, seguindo a música das vozes dos tios-avôs. Desta forma, estou sempre em estado de alerta. (Hirson, 2012, p. 149)

\section{A Mímesis de Monumentos}

Usar o mundo estático, a arquitetura, a cidade como metáfora de trabalho. A mímesis de monumentos tem por objetivo a observação de formas aparentemente estáticas do mundo arquitetural como pontes, casas, prédios, praças, ou mesmo formas aparentemente estáticas como montanhas, árvores, etc. Esse procedimento foi utilizado tanto no espetáculo solo da atriz Raquel Scotti Hirson, Alphonsus, como no solo de Renato Ferracini, Dissolva-se-me.

Mas como realizar a recriação desses monumentos?

No caso do espetáculo Alphonsus, podemos verificar como isso se dá a partir da descrição do mapa afetivo de processo de criação de Raquel Scotti Hirson:

A memória da casa. Estrutura, tijolos; o corpo tenso, denso, mas tem vida, tem movimento na imobilidade. O mofo invade por baixo e traz umidade para este corpo, que se enche de água por dentro, que incha os tijolos; água que vai encontrando espaço para passar, que penetra e transforma muito devagar. Transforma. A casatorre é úmida e verde de mofo. A casa era mesmo verde... Chegam os cupins para competir com os fungos e invadem as estruturas de madeira e o piso. Primeiro a rainha. Já viu uma? Tive que buscar as imagens para ver; confesso não ser uma experiência muito agradável. Ela pulsa em movimento contínuo, respirando, repleta de ovos dentro de si; um ser amarelo, anelado, de textura meio mole. Os cupins guardam semelhanças com as formigas ou com as baratas. A casatorre treme inteira; os bichos se apossam de seus espaços internos e a devoram. Tanto que, de casatorre, passo a ser rainha e passo a ser cupim, sou esse ser amarelo pulsante e sou esse bicho minúsculo que anda às cegas em busca de celulose para comer. Meu corpo tem que ser frágil para alcançar a pequenez deste ser, mas é forte e intenso naquela estrutura pequena; morde, ataca, come, invade. $\mathrm{O}$ corpo sai um pouco da casatorre, pois os bichos são muitos e se movem rápidos, desordenadamente. De novo espaços, vãos, pois devem passar os fantasmas, 
dançando por entre as paredes, tudo mais leve, com pouca força nas musculaturas mais profundas, o corpo quase completamente seguro pela estrutura óssea somente. (Hirson, 2012, p. 107)

Após experimentações, tropeços, erros e acertos; assim como Alphonsus, criei monumentos e fiz de uma casa monumento. Mas o tempo passou e trouxe para perto esses monumentos, os in-corporei, os "desmonumentalizei", os construí com os elementos impalpáveis ou in-corpóreos - os sonhos, os ideais, as fantasias, as energias - e com areia, cimento, tijolo - tensões, respiração, figuras, máscaras, caminhares, apoios. (Hirson, 2012, p. 140)

Ou a descrição do mapa afetivo na criação da matriz Ácaro, utilizada na montagem do espetáculo Dissolva-se-me de Renato Ferracini:

Raquel me pediu para observar as paredes da foto. A parede era o fundo, não o principal. Observar o fundo estático, imóvel: o estático da parede no estático da foto. A parede da foto era a própria parede da sala de trabalho do Lume. Ora, eu estava dentro da sala e ao invés da foto podia observar a parede, ela mesma, ali, ao vivo, branca, enorme, suja, estática, crivada de anos de suor, de marcas de mão, de reverberação de sorrisos e choros de todo o público que por ali passou. Mas na parede havia janelas com cortinas, cuja brisa as fazia dançar: uma dança de cortina suave, uma acariciar da brisa no brim escuro e puído do tecido. A coluna começa a acompanhar esse vento e uma pequena ondulação suave surge. Mas a cortina é velha, é escura, ondula crivado de ácaros em suas fibras. Imagino os movimentos de milhões, bilhões de ácaros alimentando-se da cortina, do pó. A suavidade dá lugar a uma ação desordenada, a pele cravada de ácaros. Ácaros alimentando-se de mim corpo-cortina: ação-matriz complexa: por sobre a ondulação suave da coluna, espasmos musculares gravitam sobre a pele que é casa e morada de ácaros em número infinito. Essa ação-matriz hoje inicia o espetáculo Dissolva-se-me. (Ferracini, 2015)

\section{O Experimento cênico-operativo de Dissolva-se-me}

Além da questão técnica da mímesis utilizada no processo do espetáculo Dissolva-se-me, temos nesse experimento cênico a escolha da esquizofrenia como operador poético, o que definiu algumas direções:

01) a diluição das fronteiras do normal e do patológico que se estende desde Canguilhem (1995) e Foucault (1997). A discussão social e política do termo normalidade e patologia fica mais contundente quando se trata de transtornos psiquiátricos. Afinal Estamira ${ }^{9}$ é negativamente louca ou de forma positiva vê o mundo criativa e criticamente por um perspectivismo diferenciado? A diluição da fronteira do que é patológico amplia o próprio conceito de vida ou de criação. Esse é o terreno básico que exploramos e pensamos artisticamente com esse tema nesse espetáculo.

02) em segundo lugar porque os universos corpóreos e vocais de pessoas com esses transtornos mentais, nessa fronteira diluída entre patologia e normalidade, podem produzir uma outra lógica de composição e foi, justamente essa outra lógica o mote principal de investigação poético-dramatúrgica. Não realizar uma obra que representasse a esquizofrenia ou falasse sobre a esquizofrenia, mas a própria operação

\footnotetext{
${ }^{9}$ Documentário: SINOPSE: Trabalhando há cerca de duas décadas em um aterro sanitário, situado em Jardim Gramacho, no Rio de Janeiro, Estamira Gomes de Sousa é uma mulher de 63 anos, que sofre de distúrbios mentais. O local recebe mais de oito mil toneladas de lixo da cidade do Rio de Janeiro, diariamente, e é também sua moradia. Com seu discurso filosófico e poético, em meio a frases, muitas vezes, sem sentido, Estamira analisa questões de interesse global fala também com uma lucidez impressionante e permite que o espectador possa repensar a loucura de cada um, inclusive a dela, moradora e sobrevivente de um lixão. Data de lançamento 28 de julho de 2006 ( $2 \mathrm{~h} 01 \mathrm{~min}$ ). Direção: Marcos Prado. Gênero Documentário. Nacionalidade: Brasil
} 
de construção da obra fosse esquizofrênica. A esquizofrenia como operação e não como tema. Essa postura nos possibilitou uma investigação operativa-artística do que poderia vir a ser uma esquizo-dramaturgia.

Sobre o espetáculo Dissolva-se-me em palavras da crítica e teórica de teatro Profa. Dra. Ana Maria Bulhões-Carvalho (2017, p.173, 174):

Não se sabe ainda quem seja, mas imagina-se que seja alguém com comportamento nervoso de equilíbrio e ritmos instáveis. Ele oscila lá e cá até que de costas, fala um texto desconexo em que se percebe apenas uma circulação de vida de diferentes pontos de vista referindo a seres da natureza. (Claro que depois que li a "cola" que me mandou Renato a meu pedido, pude verificar que sim, ele é Ácaro - e pensei numa hibridação do homem que quis voar ["Quando eu estou voando gotículas de gelo vão se formando nas minhas asas"] com os microscópios seres (30.000 diz o Google) causadores dos mais diversos infortúnios: alergias, preocupações na pequena vida doméstica de cada dia - o que se ouve é uma longa fala construída a partir de uma lógica irracional e solta tipo, "No natural a natureza é artificial / e se é artificial tem uma natureza natural / Roberto, Vilma, Ana, Lucas, Pedro, Natasha, todos sabem disso! / Menos o Poste / por que, Por quê, por quê?" [...] a resposta vem na mesma i-lógica que segue linhas de fuga provocadas pela proximidade de palavras e algum sentido, ainda que absurdo, se entre elas se pode estabelecer, em série, significantes sem referentes. A um comando de voz a chamar "Sr. Renato, Sr. Renato" que começa e solicitar "tarefas" precisas, que o histrionismo do ator passa a oferecer, mudando a postura corporal, o gesto, a expressão do olhar: "uma Tulipa azul", que da primeira vez ele não faz a contento, e a voz corrige; "Não Sr. Renato, isso é uma Borboleta Amarela". Não sei explicar porque a partir deste momento instala-se uma emoção mais forte, uma dor que vai se transformando em compaixão: é isso que fazem com os loucos num hospício? Pensei, os medicamentos e os comandos repetidos vão condicionando comportamentos para "socializá-los?" Esse processo os acalma ou os exaspera. Aquele Sr. Renato ali parece alterado. Vira um Monstro assustador, seus traços fisionômicos se contorcem, fazem pensar nos quadros do Francis Bacon e nas distorções a que submete suas figuras retratadas. [Mais pra frente ele mesmo dirá: "Bacon nunca se contentou com a forma absoluta. Ele sempre teve a maestria de manipular a forma formada"]. Ele diz "Eu tenho em mim a complexidade de nitrogênios". Faz sentido, a partir do momento em que aceito o louco, tudo vai sendo mais compreensível e tocante. [...], lembro-me de ter saído muito triste da sala, afetada por ideias e emoções relativas a fenômenos e seres cujo convívio exige mais doação e paciência do que em geral estamos disponíveis a dar. Sem trazer objetivamente um tema, a composição cênica de Renato/Sr. Renato representou um espaço ao qual não pertenço, apresentou-me um ser que não conheço, mas que em traços reconheço. Saí um pouco melhor dessa experiência. A ética proposta e convocada foi na direção da aproximação humana, da consciência da diferença.

\section{Próximos passos...}

Esses procedimentos técnicos e operativos elencados acima foram verticalizados e experimentados em processos diversos e diferenciados anteriormente em 3 solos: Alphonsus de Raquel Scotti Hirson (mímesis corpórea e suas ramificações: mímesis da palavra e mímesis de monumentos), Você de Ana Cristina Colla (contaminações entre butô, mímesis e dança pessoal) e Dissolva-se-me de Renato Ferracini (mímesis de monumentos e operação esquizo-dramatúrgica). Cada ator/atriz, portanto, experimentou e criou de forma singular procedimentos outros que expandiram a potência da mímesis corpórea, mesmo que esses procedimentos apresentem pontos em 
comum: seja o conceito de memória e de metáforas de trabalho, seja o fato de todos eles utilizarem como foco de análise comum os mapas afetivos em cada processo.

Um próximo passo seria unificar e reunir esses procedimentos com o objetivo de sua re-sistematização. Propor uma nova composição, um novo agenciamento entre essas formalizações e procedimentos diversos da mímesis. Percebemos que não existem, de fato, fronteiras, nem linhas que os separe, mas espaços de tensão, um "entre", uma zona de turbulência, um espaço de Devir, uma zona de experiência e contaminação que pode e deve ser explorada, sistematizada e futuramente disponibilizada em processos pedagógicos.

\section{Referências}

BACHELARD, Gaston. A Poética do Devaneio. Tradução Antônio de Pádua Danesi. São Paulo: Martins Fontes, 1988.

BARTHES, Roland. Diário de Luto. Tradução Miguel Serras Pereira. Lisboa: Edições 70, 2009.

BURNIER, Luís Otávio. A Arte de Ator: da Técnica à Representação - Elaboração, Codificação e Sistematização de Técnicas Corpóreas e Vocais de Representação para o Ator. Campinas: Unicamp, 2001.

CANGUILHEM, G. O normal e o patológico, trad. Maria Thereza Redig de Carvalho Barrocas e Luiz Octavio Ferreira Barreto Leite. - 4a. Ed.- Rio de Janeiro, Forense Universitária, 1995.

COLLA, Ana Cristina. Caminhante, Não Há Caminho. Só Rastros. São Paulo: Perspectiva: Fapesp, 2013.

Cartografia dos Corpos em SerEstando Mulheres. Relatório Científico vinculado ao Projeto de Pesquisa Regular - Fapesp "SerEstando Mulheres". Campinas: 2014. Mimeo.

FERRACINI, Renato. Diário de trabalho do processo criativo do espetáculo DISSOVA-SE-ME, Campinas, 2015. Mimeo

FOUCAULT, Michel. A História da Loucura na Idade Clássica. São Paulo, Perspectiva, 1997.

GIL, José. A Imagem-Nua a as Pequenas Percepções - Estética e Metafenomenologia. Lisboa: Relógio D'Agua Editores, 2005.

GIL, José. Transcrição Palestra José Gil. Revista Ilinx. LUME - UNICAMP, Campinas, n.1, 2012. Disponível em http://www.cocen.rei.unicamp.br/revistadigital/index.php/ lume/article/view/116. Acesso: 21 de Junho de 2017. 
GUIMARAENS, Alphonsus de. Obra Completa. Rio de Janeiro: José Aguilar, 1960.

HIRSON, Raquel Scotti. Alphonsus de Guimaraens: Reconstruções da Memória e Recriações no Corpo. Tese de Doutorado. Instituto de Artes, Unicamp, Campinas, 2012.

TELLES, Narciso; FERRACINI, Renato; BULHÕES-CARVALHO, Ana Maria; CARREIRA, André. Representação e Ética. Periódico OuvirOUver. Uberlândia, Número 13 janeiro/junho 2017. Disponível em: http://www.seer.ufu.br/index.php/ouvirouver/article/ view/36977/20405 Acesso em: 21de junho. 2017.

UNO, Kuniichi. A Gênese de um Corpo Desconhecido. Tradução de Christine Greiner com a colaboração de Ernesto Filho e Fernanda Raquel; prefácio de Christine Greiner. 2a ed. São Paulo: n-1 edições, 2012.

Recebido em: 30/06/2017 Aprovado em: 12/10/2017 